\title{
Sunda Language Reservation in Cianjur ON THE AGE TO LEARN
}

\author{
Wati Kurniawati $^{1)}$, Emzir $^{2)}$, Sabarti Akhadiah $^{3)}$ \\ ${ }^{1)}$ Badan Pengembangan dan Pembinaan Bahasa, Indonesia \\ Email: watikurniawati62@yahoo.com \\ ${ }^{2)}$ State University of Jakarta, Indonesia \\ Email:Emzir.unj@gmail.com \\ ${ }^{3)}$ State University of Jakarta, Indonesia \\ Email: sabartiakhadiahj@yahoo.com
}

\begin{abstract}
This study aims to gain an understanding of Sundanese language reservation in Kota Cianjur at the compulsory school age. The observations focused on the domains of Sundanese use that included the family and education sphere. The problem in this research is how the reservation of Sundanese language is viewed from the point of choice of language with the domain of its use? In this research used qualitative approach with ethnography method. The ethnographic research procedure in this study is 1) define sub focus, 2) observation and interview, 3) collect data, 4) make notes, 5), analyze data, and 6) make ethnographic reports. The research findings show that the form of speech is a statement, a question, a greeting, a thank-you note, a formula phrase, a solicitation, a request to do something, an apology, an order, and an agreement. Based on the Sundanese language reservation category in Cinajur city at the compulsory education age in the family realm is maintained $(85-100 \%)$. The participants of Sundanese speech have a positive loyalty and attitude towards the language. Meanwhile, the education sphere is less maintained (51-74\%). In the realm of education, there can be a shift in language because it is poorly maintained and the said participants have no balance in lending languages.
\end{abstract}

Keywords: Reservation; Ethnographic Methods; Domains

\section{INTRODUCTION}

In Indonesia, the number of Sundanese speakers is the second largest language sequence after the Java language. According to the 2000 census data, the language of Sunda is spoken by 34 million people (Koran Sindo, 2017). According to Harsojo (2007), Sundanese tribes are people who are hereditary using the mother tongue of Sundanese language and dialect in everyday life and come and live in area of West Java, area which also often called Tanah Pasundan or Tatar Sunda. In the use of Sundanese is known division of three levels, namely Sundanese language lemes, medium, and rough.

Based on the calculation of dialectometry, this Sundanese isolate is divided into three dialects, namely (1) dialect [h], (2) non-dialect [h], and (3) dialect [o]. The percentage difference between the three dialects is about 60\% (Language Mapping
Team, 2017). The people of West Java and Banten are bilingual or multilingual communities. The Sundanese in Kota Cianjur uses Sundanese which includes dialect [h]. Besides Sundanese, hereinafter abbreviated as BS as mother tongue, used Indonesian language, hereinafter referred to as BI.

BS as a regional language hereinafter abbreviated as $\mathrm{BD}$ is a minority language, while $\mathrm{BI}$ is the majority language in Indonesia. Use of BI can shift BD. However, the two languages co-exist and are protected by the State as stated in Law No. 24 of 2009 on Flags, Languages and State Symbols, as well as the National Anthem, Articles 41 and 42.

Sundanese as the mother tongue of Cianjur city community is used among its own, while Indonesian language is used between different techniques. The interaction of these two types of language has an impact on the pattern of language usage in the community. This pattern of language 
usage can cause the language in the ethnic itself to shift due to switching to using the Indonesian language in communicating inter-ethnic. The use of both languages is indirectly the speakers become bilingual. In this speech community, there is a domain (domain) the use of language that determines the rules of use of a particular language in each domain. The dominant use of the Indonesian language creates situations and conditions that threaten the mother tongue.

Language preservation is directed at bilingual societies that can occur in diglossic societies that retain the use of a language for different functions and in different domains. The use of language in the family domain is very important for the preservation of a language. If the language is in a community said not used in the family domain, the mother tongue will be shifted.

Based on observations, Sundanese language reservation in Cianjur City shows the Sundanese ethnic community to date have a positive loyalty and attitude towards its language. Speakers aged 15 and underuse Sundanese and Indonesian language interchangeably depending on the setting, situation, participants, context, and domain of the language used.

The reason for the study of Sundanese language reservation was (1) Cianjur as the center of inter-ethnic activities using Sundanese as a means of communication except with Indonesians; (2) Kota Cianjur is one of the tourism crossing areas of Jakarta-Bandung and Sukabumi-Bandung. Therefore, it is necessary to examine the domain of Sundanese language that shows the reservation or shift of language.

The use of language in the community is influenced by social factors, such as social status, education level, age, and gender. In addition, language forms are influenced by situational factors such as who speaks, to whom, when, where, and the topic of conversation. This study included ethnographic communication research. Ethnographic research focuses on the analytic aspects of social science which are branches of cultural anthropology (Wardhaugh and Janet M. Fuller, 2015).

Language preservation (language maintenance) is called language maintenance. Language preservation is a decision to keep the language spoken by the speech community who have previously used the language. According to Harimurti (2013), language maintenance is an attempt to keep a language spoken and valued, especially as a group identity, in the language community concerned through teaching, literature, mass media, and so on. Meanwhile, Holmes (2015: 61) says that "Without active language maintenance, shift is almost inevitable in many contexts" ('without active language preservation, language shift is almost inevitable in many contexts').
BS's reservation research is reviewed based on the language behavior of groups and not individuals so that the linguistic aspects in the social context are examined. Language reservation in this study is the behavior of language in groups in the community. The problem in this research is how BS reservation is viewed from the angle of choice of language with the domain of its use? This study aims to gain an understanding of Sundanese reservation in Cianjur City. The observations focused on the domains of Sundanese use that included the family and education sphere.

Language preservation in the language community can occur passively and actively. Passive language reservation is that speakers of the language do not use the language in accordance with its function as a regional symbol. Speakers of that language consider the local language as a symbol of identity whose attitude is not in line with language behavior in language activities. In that context, there is a shift in language. Meanwhile, active language activity is a connection between language and social context. The language community always uses its language in the domains traditionally possessed by the language. In this context, there is language preservation. Thus, in the first context, there is a shift in language, whereas in the second context there is language preservation (Siregar et al., 1998).

Meanwhile, Selvia (2014) in his research found two factors supporting the reservation of Sundanese language in the village of Sarireja. The two factors are (1) loyalty to the mother tongue and (2) the family environment. It is also said that three factors of Sundanese reservation in Sarireja Village are: (1) population movement, (2) economic factors, and (3) different interethnic marriage factors.

\section{Methodology}

This research was conducted in Cianjur City, Cianjur Sub-district, Cianjur Regency in 2017. The subjects of this study were participants of speech (mandatory age of 6-15 years) in Sundanese in Cianjur City. In this research used qualitative approach with ethnography method. Gay L.R. et al. (2009) states that a qualitative approach is a way of looking at the problem more deeply to provide an understanding of a research object or research participant. Meanwhile, Moleong (2012: 6) said that qualitative research is a study that intends to understand the phenomenon of what is experienced by research subjects, such as behavior, perception, motivation, action, holistically and by way of description in the form of words and language, in a special, natural context and by utilizing various scientific methods.

Spradley (1980) says that ethnography is a work that describes a culture that encompasses three aspects: cultural behavior 'what is done', what 
cultural knowledge 'is known, and what' cultural artifacts' are used. This ethnographic research procedure is adapted from Spradley (1997: 57; 2007).

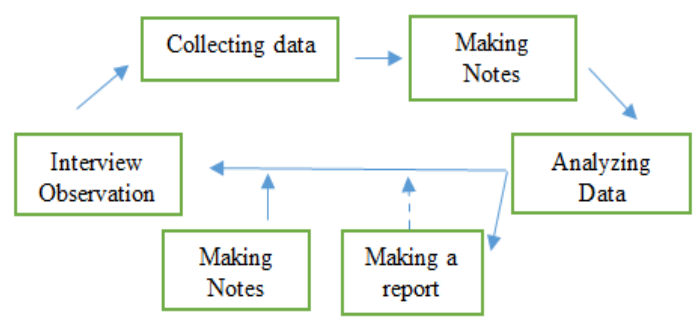

Fig.1 Ethnographic Research Procedure

Text analysis method used is content analysis. According to Krippendroff (2004), the definition of content analysis is "a research technique for making replicable and valid inferences from texts (or other meaningful matter) to the contexts of their use. Meanwhile, Emzir (2012) states that content analysis is an in-depth analysis that can use both quantitative and qualitative techniques on messages using the scientific method and not limited to the types of measurable variables or the context in which messages are created or presented.

The data in this study is the primary data on Sundanese language reservation. Data is an interview transcript and field note or observation. Data in terms of words, phrases, and sentences are calculated on a percentage basis. Secondary data as support in the form of documents or writings related to the community said Sundanese.Sumber of data directly related to the problem studied, namely Sundanese speech people who live and live in the City of Cianjur.

The classification of language preservation consists of five levels of categories, ranging from safe language to extinct languages (Crystal, 2002). In this study language retention is reduced to four levels because it does not include extinct categories, ie 1) strongly maintained $(85-100 \%), 2)$ maintained (75-$84 \%), 3)$ less maintained n $(51-74 \%)$, and 4) are not maintained $(0-50 \%)$.

\section{RESULTS AND DISCUSSION}

The domain or use of language refers to a specific place. Cultural domains are categories of cultural meanings that belong to other smaller categories (Spradey, 1980). In the activity of telling who knows the steps are always considered a smooth or rough speech. The speech depends on the person's attitude to the speech situation he is facing. Here is an example of Sundanese speech in the family realm.

Here is the dialogue between Reza (A) and Mr.Ujang (B)

A1: Asalamualaikum, Bapa Ujang. Aya Reza?
'Asalamualaikum, Mr. Ujang. Is Reza here?'

B1: Waalaikum Salam, aya di pengker.

'Waalaikum Salam, he is in the backyard.'

The language used in the speech includes Sundanese subtle. Reza started the greeting by saying his partner, Mr. Ujang with the words "Asalamualaikum, Mr. Ujang". The following lines are questions. In relation to the greeting, the partner also replied the greeting with the speech "Waalaikum Salam." Mitra said to answer the question with a statement.

The following example is a form of questioning.

A2: Dupi Fadlan ka mana?

'Then, where is Fadlan?'

B2: Fadlan masih di sakola. Mangga ka lebet Reza.

'Fadlan still in the school. Please come in Reza.'

Speaker's speech is a question. The response of the said partner includes a statement for fulfilling the speaker's requests by providing Fadlan's whereabouts.

Here is an example of a speech that serves to express gratitude.

A3: Hatur nuhun, Bapa Ujang.

'Thank you, Mr. Ujang.'

B3: Mangga lebet, Reza.

'Please come in, Reza.'

Reza stated "hatur nuhun" to Mr. Ujang in his statement. Mitra said to rule Reza to do something.

Here's an example of a dialogue between Luti (A) and Mamah Tito (B).

A1: Asalamualaikum, Mamah Tito.

'Asalamualaikum, Mamah Tito.

B1: Waalaikum salam, Neng Luti. Mangga calik, geulis.

'Waalaikum salam, Miss Luti. Please take a seat, beautiful.'

The language used in the speech includes Sundanese subtle. Tuturan begins by greeting his partner, namely Mamah Tito with Asalamualaikum speech, Mamah Tito. The words "Asalamualaikum" are formula expressions. The next line is a statement. In relation to the greeting, the partner also replied to the greeting with the words "Waalaikum salam". The saying "Waalaikum salam" is a formula expression. Then, the partner said and ordered Neng Luti to do something. Mitra said to greet Luti with the title for girls, that is "Neng" and praised with the title "geulis".

The following example serves to declare statements, phrases, questions, and statements.

A2: Ieu cau sareng kueh. Punten, Mah! Abdi moal lami.

'This is banana and cake. I'm sorry, Mah! I cannot stay long.'

B2: Hatur nuhun, Neng. Saurkeun ka Ibu. Naha enggal-enggalan? Salam ti Mamah kanggo Ibu. 
'Thank you, Miss. Please tell your Mother. Why hurry up? Greetings from Mamah to your Mother.'

In that example Luti informs Mamah. Next, the speaker declares apologize and reason. Partner said thank you, "Hatur nuhun" and the request to be submitted to someone. Furthermore, the said partner responds to an apology with a rhetorical question of the speaker. Mitra said he ended his conversation with the expression of the formula, namely "Salam ti Mamah kanggo Ibu".

Here are examples of Sundanese speech between Ica (A) and Tea Ani (B).

A1: Teh Ani maen papasakan. Hayu!

'Miss Ani, Let's play cooking!'

B1: Di mana, Ica?

'Where is Ica?'

In that quote, Ica starts the utterance with a statement. Then, the speaker declares an invitation to the speech partner. Speaking partners respond to speaker's speech by using questions.

The following lines serve to declare statements, solicitation, and questions.

A2: Di payun. Ieu parabotna.

'In front of the house. These are the equipment.'

B2: Hayu, urang tata parabotna! Mana sayuranna?

'Come on, we tidy up the equipment! Where are the vegetables?'

Speaker's speech responds to a question by declaring a statement. Speaking partners invite speakers to take action. Furthermore, the partner said the question.

Here is a speech that serves to declare statements and solicitation.

A3: Ieu seueur sayuranna.

'It's a lot of vegetables.'

B3: Urang pasak sayuranna di panci.

'We cook the vegetables in the pan.'

The speaker responds to the partner's question with a statement. Speaking partners invite speakers to take action.

Here is the excerpt from a conversation between Dudung (A) and Udin (B) when going to play ball in the realm of education.

A1: Udin bade ka mana?

'Udin, where do you want to go?'

B1: Ka lapangan maen bal.

'I want to go to the football field to play football'.

In the quote, Dudung states the question. The said partner responds to the speaker's question with a statement.

Here is a form of speech that serves to declare a request and solicitation.

A2: Abdi ngiring nya.

'Saya ikut ya.'

B2: Hayu, Dudung! Urang nyampeur Asep, Usep, jeung Dikdik heula.
'Come on, Dudung! We meet Asep, Usep, and

Dikdik first.

The speaker responds to the statement of the said partner with the request. Speaking partners invite speakers to take action. Then, the partner said the statement.

The following speech that serves to declare statements and information.

A3: Enya.

'yes'.

B3: Itu Asep, Usep, jeung Dikdik keur nungguan.

'Asep Usep, and Dikdik are waiting.'

The speaker agrees with the previous partner's statement. Partners said a statement of information.

A4: Di lapangan geus aya saha, Udin?

'Who's on the field?, Udin?'

B4: Rudi, Ohim, Redi, Sobur, Amir, jeung Budi geus ngumpul.

Ohim, Redi, Sobur, Amir, and Budi have been gathered.'

In the quotation, the speaker expresses the question. The said partner responds to the speaker's question with a statement.

Here is an example of Sundanese language utterance smooth and is in the realm of education or school. Here is a quote between student (A) and Teacher (B).

A1: Wilujeng enjing, Pa Guru!

'Good Morning, Sir!'

B1: Wilujeng enjing, Barudak! Ayeuna urang diajar tatarucingan.

'Good morning, students! Now we are learning the riddle.'

Speaker's speech is a form of expression to the speech partner, the teacher. The said partner replied with formula and statement expressions.

The following lines are statements, questions, and statements.

A2: Sumuhun, Pa Guru!

'Yes, sir!'

B2: Budak leutik teuteuleuman. Saha anu terang hartosna?

'Small children diving. Who knows what that means?'

C1: Abdi, Pa Guru. Hartosna gayung.

'Me, sir. It means scoop.'

Speaker's speech is a statement to the partner said, that is Teacher. Partners said express statements and questions. The speech partner (C) responds to Master's questions with the statement.

Here's the conversation between Master (B) and students (D and E).

B3: Leres, Adi. Saha anu gaduh tatarucingan?

'Right, Adi. Who has a riddle?'

D1: Abdi, Pa Guru. Budak leutik ngambay peujit. 'Me, sir. Small children take intestines."

E1: Hartosna jarum.

'It means needle.' 
Speaker's speech is a statement and a question. The speech partner (D) responds to Master's question with a statement. The said partner (E) responds to a friend's question with a statement.

The following lines serve to declare statements, commands, and statements.

B4: Leres, Ani. Barudak, ayeuna latihan paribasa di halaman 58 dugi ka halaman 59 diapalkeun.

'Right, Ani. Children, now we practice proverb by memorizing page 58 to page 59.'

A3: Sumuhun, Pa Guru.

'Yes, sir.'

Speech (B4) is a statement and a command. Speak (A3) is a response to a command expressed in the form of a statement.

Here is an example of Sundanese speech when students take a break at school (education sphere). Here's the conversation between Entin (A) and Evi (B) when to Canteen.

A1: Evi bade jajan

'Evi, do you want to buy some snacks?.'

B1: Bade, ari Entin mau jajan apa?

'Yes, I do. What snacks do you want to buy?

In that speech, the speaker declares a solicitation. Speaking partners respond to speakers' requests with statements and questions.

Here are examples of speech statements and questions.

A2: Kue donat.

'I want to buy donut.'

B2: Bekel sabaraha?

'How much do you have?'

Speaker response is a statement. Partners said the question.

The following speech example works to express statements and questions.

A3: Tiga ribu.

"Three thousand.'

B3: Oh, Tin uang jajannya berapa?

'And you? How much do you have?'

Speaker response is a statement. Partners said the question.

Here are examples of speech statements and questions.

A4: Empat ribu.

'Four thousand'

B4: Mau beli apa?

'What do you want to buy?'

The speaker said the statement. Meanwhile, the partner said the question.

The following speech example works to express statements and questions.

A5: Nasi goreng.

'I want to buy fried rice.'

B5: Hayu Kita ke kantin!

'Let's go to the canteen!'

Speaker response is a statement. Meanwhile, the partner said the call.
Conversation Amen (A) and Dede (B) when to library

A1: Ayo, Min ke perpustakaan.

B1: Hayu, De! Nyari buku cerita apa?

The speaker in the quotation declares a solicitation. Partner said the call and ask questions.

Here's an example of a speech that states statements, questions, and questions.

A2: Cerita Lutung Kasarung.

B2: Saya mau cari buku naonnya? Oh, seni budaya Sunda.

Speaker response is a statement. Meanwhile, the partner said the questions and statements.

The following speech example states a statement.

A3: Anu kanggo tugas.

B3: Ya.

Speaker's utterance is a statement to the said partner, namely Dede. Partners said the statement.

statement

Here's an example of a speech that states a

A4: Saya sudah buat kemarin.

B4: Nanti pulang sekolah saya buat tugasnya.

Speakers and said partner are statements. Statement of the said partner shows the information.

Based on the data of the analyzed speech, the effective use of Sundanese is dependent on the speaker and the speech partner. Things that are not described literally can be expressed by speakers and partners said at the time of conversation. Response partners said there are literally communicative and less communicative.

The following Table I shows the categories of Sundanese language reservation in the family realm.

Table I

Percentage of Sundanese Language Reservation in the Family Area

\begin{tabular}{llcc}
\hline No. & Language & Frequency & Percentage (\%) \\
\hline 1. & Sundanese & 17 & 100 \\
\hline 2. & Indonesian & - & \\
\hline 3. & Sundanese and Indonesian & - & \\
\hline & Total & 17 & 100 \\
\hline
\end{tabular}

Table I shows that the percentage of speakers' speech is in Sundanese $(100 \%)$. Based on the Sundanese language reservation category in Cinajur city at the compulsory education age in the family realm is maintained $(85--100 \%)$. Thus, the percentage of speech speakers in Sundanese is $100 \%$ means to be in a highly defensible category.

The following Table II shows the categories of Sundanese language reservation in the education sphere.

Table II

Percentage of Sundanese Language Reservation in the Education Sphere 


\begin{tabular}{llcc}
\hline No. & Language & Frequency & Percentage $(\%)$ \\
\hline 1. & Sundanese & 20 & 55,5 \\
\hline 2. & Indonesian & 13 & 36,1 \\
\hline 3. & Sundanese and Indonesian & 3 & 8,4 \\
\hline & Total & 36 & 100 \\
\hline
\end{tabular}

Table II shows that the percentage of speakers' speech in Sundanese $(55, \%)$. Based on the category of reservation, Sundanese in Cianjur city at the age of compulsory education in the education sphere less maintained (51-74\%). Thus, the percentage of speech speakers in Sundanese is $55 \%$ means to be in a less sustainable category.

\section{CONCLUSION}

Based on data analysis, it was concluded that the speakers' speech was to express statements, questions, greetings, thank-you, formula expressions, solicitation, requests to do something, apologies, orders, and approvals. Sundanese reservation in the family realm based on the Crystal category (2002) reduction category, which is strongly maintained (100\%). The participants of Sundanese speech have a loyalty and a positive attitude towards the language. However, Sundanese reservation in the education sphere is poorly maintained $(55.5 \%)$. In the nursery school at the compulsory education, age is taught Indonesian language with more hours than the Sundanese language lessons. If the speaker has no balance in language borrowing, language shifts may occur.

To obtain information one needs to have a dialogue. The participants should pay attention to the content of the speech so that the dialogue can take place communicative and effective. This is closely related to the response given by the participants.

\section{REFERENCES}

Alwi, Hasan dkk. 2017. Tata Bahasa Baku Bahasa Indonesia. Edisi Keempat. Jakarta: Badan Pembinaan dan Pengembangan Bahasa.

Crystal, David 2002. Language Death. Cambridge: Cambridge University.

Emzir. 2012. Metodologi Penelitian Kualitatif: Analisis Data. Jakarta: RajaGrafindo Persada.

2012. Metodologi Penelitian Pendidikan: Kualitatif \& Kualitatif. Jakarta: RajaGrafindo Persada.

Gay L.R., et al. 2009. Educational Research Competences for Analysis and Applications. Edition IX. New Jersey: Pearson.

Harsojo. 2007. "Kebudayaan Sunda" dalam Koentjaraningrat (Redaksi) Manusia dan kebudayaan di Indonesia. Jakarta: Pustaka Jaya.
Holmes, Janet. 2015. An Introduction to Sociolinguistics. Fourth Edition. New York: Routledge.

Kabupaten Cianjur. 2016. "Sekilas Cianjur”. http://www.cianjurkab.go.id/Content Nomor_Menu_15_3.html. Diunduh 1 Februari 2016.

Koran Sindo. 2017. Ini Dia 10 Bahasa Daerah dengan Penutur Terbanyak di Indonesia”.

Senin, $\quad 30 \quad$ Oktober 2017. https://nasional.sindonews.com/read/125285 3/15/ini-dia-10-bahasa-daerah-denganpenutur-terbanyak-di-indonesia1509344321. Diunduh 5 Maret 2018.

Kridalaksana, Harimurti. 2013. Kamus Linguistik. Jakarta: Gramedia Pustaka Utama.

Krippendorff, Klaus. 2004. Content Analysis: An Introduction to Its Methodology. London: Sage Publications.

Moleong, Lexy J. 2012. Metodologi Penelitian Kualitatif. Bandung: Remaja Rosdakarya.

Panitia Kamus Lembaga Basa jeung Sastra Sunda. 2007. Kamus Umum Bahasa Sunda. Bandung: Geger Sunten.

Undang-Undang Republik Indonesia Nomor 24 Tahun 2009 tentang Bendera, Bahasa, dan dan Lambang Negara, serta Lagu Kebangsaan. 2016. Jakarta: Badan Pengembangan dan Pembinaan Bahasa.

Selvia, Amanda Putri. 2014. "Sikap Pemertahanan Bahasa Sunda dalam Konteks Pendidikan Anak Usia Dini (Kajian Sosiolinguistik di Desa Sarireja, Kecamatan Jalan Cagak, Kabupaten Subang)" dalam Jurnal Bahtera Sastra: Antologi Bahasa dan Sastra Indonesia. Linguistik: No.1, Agustus 2014. http://ejournal.upi.edu/ index. php/BS_Antologi_Ind/article/view/461. Diunduh 1 Februari 2016.

Siregar, Bahren Umar dkk. 1998. Pemertahanan Bahasa dan Sikap Bahasa Kasus Masyarakat Bilingual di Medan. Jakarta: Jakarta: Pusat Pembinaan dan Pengembangan Bahasa.

Spradley, James P. 1980. Participant Observation. New York: Holt Rinehart and Winston.

1997. Metode Etnografi (Penerjemah Misbah Zulfa Elizabeth). Yogyakarta: PT Tiara Wacana.

2007. Metode Etnografi (Penerjemah Misbah Zulfa Elizabeth). Yogyakarta: PT Tiara Wacana.

Tim Pemetaan Bahasa. 2017. Bahasa dan Peta Bahasa di Indonesia. Jakarta: Badan Pengembangan dan Pembinaan Bahasa.

Tim Redaksi Kamus Besar Bahasa Indoesia. 2017. Kamus Besar Bahasa Indonesia. Jakarta: Badan Pengembangan dan Pembinaan Bahasa. 
Wardhough, Ronald dan Janet M. Fuller. 2015. An Introduction to Sociolinguistics. Seventh Edition. New York: Basil Blackwell. 